\title{
Acquisition of intact polar lipids from the prymnesiophyte Phaeocystis globosa by its lytic virus PgV-07T
}

\author{
D. S. Maat ${ }^{1, * *}$, N. J. Bale ${ }^{1, * *}$, E. C. Hopmans ${ }^{1}$, A.-C. Baudoux ${ }^{*}$, J. S. Sinninghe Damsté ${ }^{1}$, S. Schouten ${ }^{1}$, and \\ C. P. D. Brussaard ${ }^{1,2}$ \\ ${ }^{1}$ Departments of Biological Oceanography and Marine Organic Biogeochemistry, Royal Netherlands Institute for Sea \\ Research, P.O. Box 59, 1790 AB Den Burg, the Netherlands \\ ${ }^{2}$ Aquatic Microbiology, Institute for Biodiversity and Ecosystem Dynamics, University of Amsterdam, P.O. Box 94248, 1090 \\ GE Amsterdam, the Netherlands \\ * present address: CNRS and UPMC Univ Paris 06, UMR7144, Station Biologique de Roscoff, Place Georges Teissier, 29680 \\ Roscoff, France \\ ** These authors have contributed equally to the manuscript.
}

Correspondence to: D. S. Maat (douwe.maat@nioz.nl)

Received: 26 June 2013 - Published in Biogeosciences Discuss.: 12 July 2013

Revised: 4 December 2013 - Accepted: 4 December 2013 - Published: 14 January 2014

\begin{abstract}
Recent studies showed changes in phytoplankton lipid composition during viral infection and have indicated roles for specific lipids in the mechanisms of algal virus-host interaction. To investigate the generality of these findings and obtain a better understanding of the allocation of specific lipids to viruses, we studied the intact polar lipid (IPL) composition of virally infected and noninfected cultures of the prymnesiophyte Phaeocystis globosa $\mathrm{G}(\mathrm{A})$ and its lytic virus PgV-07T. The P. globosa IPL composition was relatively stable over a diel cycle and not strongly affected by viral infection. Glycolipids, phospholipids and betaine lipids were present in both the host and virus, although specific groups such as the diacylglycerylhydroxymethyltrimethyl- $\beta$-alanines and the sulfoquinovosyldiacylglycerols, were present in a lower proportion or were not detected in the virus. Viral glycosphingolipids (vGSLs), which have been shown to play a role in the infection strategy of the virus EhV-86, infecting the prymnesiophyte Emiliania huxleyi CCMP374, were not encountered. Our results show that the involvement of lipids in virus-algal host interactions can be very different amongst virus-algal host systems.
\end{abstract}

\section{Introduction}

Phytoplankton are the primary source of a large variety of organic compounds, including lipids. In the marine food web these lipids are not only an important nutritional source of carbon, but also contain substantial amounts of phosphorus and nitrogen. Several phytoplankton species belonging to the class Prymnesiophyceae are considered important players in organic carbon and sulfur cycling worldwide (Smith et al., 1991; Arrigo et al., 1999; Stefels and van Boekel, 1993; Moon-van der Staay et al., 2000). Phaeocystis globosa is an ecologically important species in temperate coastal regions (Schoemann et al., 2005), and can be a substantial source of intact polar lipids (IPLs) in particulate organic matter (Brandsma et al., 2012b). This species is found in a single-celled flagellate stage as well as in colonies, and can develop dense blooms (see review by Schoemann et al., 2005). Blooms of $P$. globosa have been reported to be terminated or even prevented by viral infection (Brussaard and Martínez Martínez, 2008). Phytoplankton viruses play a fundamental role in the marine food web. Through the lysis of their algal hosts, viruses release nutritional compounds from the cells into new pools of dissolved and particulate organic matter - a process called the viral shunt (Wilhelm and Suttle, 1999). Viral infection may also affect the cellular composition of the infected host. Evans et al. (2009) have shown 
that viral infection of the prymnesiophyte Emiliania huxleyi CCMP1516 can affect the host fatty acid composition. Viruses can thus potentially alter the composition of lipids in phytoplankton.

Additionally, it has been shown that lipids can play a role in the interaction between viruses and their algal hosts as elegantly shown for the phytoplankton-virus model system $E$. huxleyi CCMP374 and its virus EhV-86 (Vardi et al., 2009). Viral infection induced the production of specific viral glycosphingolipids (vGSLs) in cells of E. huxleyi that seem to play a role in a programmed cell death mechanism of the host and the timing of cell lysis. These compounds are found in the virus itself as well. In a natural coccolithophore population, it was shown that these lipids may be used as biomarkers for viral infection of phytoplankton (Vardi et al., 2012). Members of the Group I P. globosa viruses (PgVs) belong to the nucleocytoplasmic large DNA viruses (NCLDVs) (Brussaard et al., 2004). Many NCLDVs are known to possess a lipid membrane (Van Etten et al., 2010), that have been found to span the inner side (Yan et al., 2005) or the outer side of the capsid (Mackinder et al., 2009). However, questions remain about the acquisition and composition of the lipids in these membranes.

In this study we investigated the composition of IPLs in the prymnesiophyte $P$. globosa, before and during viral infection with $\mathrm{PgV}-07 \mathrm{~T}$, the most intensively studied $P$. globosa virus strain to date (Baudoux and Brussaard, 2005, 2008; Sheik et al., 2013). Our aims were to detect possible changes of the host IPLs induced by the virus and, since many NCLDVs possess a membrane, clarify the IPL composition of the possible viral membrane as well. Additionally, we aimed to compare our findings to specific IPL dynamics in the phylogenetically related phytoplankton species $E$. huxleyi, in which vGSLs play an important role in the mechanisms of viral lysis.

\section{Materials and methods}

\subsection{Culturing conditions}

Axenic cultures of Phaeocystis globosa G(A) (culture collection of the University of Groningen, The Netherlands) were grown in batch cultures at $15^{\circ} \mathrm{C}$ in a $1: 1$ mixture of f/ 2 medium (Guillard, 1975) and modified artificial seawater (ESAW, Harrison, 1980), i.e. enriched with Tris- $\mathrm{HCl}$ and $\mathrm{Na}_{2} \mathrm{SeO}_{3}$ (Cottrell and Suttle, 1991). Irradiance was supplied at $90 \mu \mathrm{mol}$ quanta $\mathrm{m}^{-2} \mathrm{~s}^{-1}$ under a $16 \mathrm{~h}$ light: $8 \mathrm{~h}$ dark cycle. The lytic P. globosa virus, PgV-07T (Baudoux and Brussaard, 2005) was derived from the virus culture collection of the Royal Netherlands Institute for Sea Research. This double-stranded DNA (dsDNA) virus, belonging to $\mathrm{PgV}$ Group I with a genome size of $470 \mathrm{kbp}$ and a diameter of approximately $150 \mathrm{~nm}$ (Baudoux and Brussaard, 2005), was cultured under the same conditions on exponentially growing
P. globosa. Both culture and lysate were regularly checked for axenity by epifluorescence microscopy, using the nucleic acid stain 4',6-diamidino-2-phenylindole, dihydrochloride (DAPI) (Life technologies Ltd. Paisley, UK). The cultures were axenic at all times during the experiments.

\subsection{Detection of viral membrane}

The presence of a lipid membrane in $\mathrm{PgV}-07 \mathrm{~T}$ was confirmed by staining fresh viruses with the lipophilic dye $\mathrm{N}$-(3-triethylammoniumpropyl)-4-[4-(dibutylamino)styryl] pyridinium dibromide (FM 1-43) (Life technologies Ltd. Paisley, UK) in TE buffer $(\mathrm{pH}=8)$ at a final concentration of $10 \mu \mathrm{M}$ for $10 \mathrm{~min}$. Viral particles were detected using a benchtop BD FACSCalibur equipped with a $488 \mathrm{~nm}$ argon laser (BD Biosciences, San Jose, USA), after setting the trigger on green fluorescence. Additionally, to test whether this lipid membrane was required for the infectivity of $\mathrm{PgV}$, freshly produced viral lysate was treated with diethyl ether and chloroform (98 and 99\%, respectively; J. T. Baker). Both solvents have been shown to be effective indicators of lipids in viruses (Feldman and Wang, 1961), including those of viruses containing an inner membrane (Olsen et al., 1974; Bamford et al., 1995). Separate incubations with 10 or $50 \%(v / v$ final concentration) of either of the two compounds were performed at room temperature for $60 \mathrm{~min}$. After incubation, the solvent from the samples treated with diethyl ether was removed from the virus suspension just by evaporation (overnight at $4{ }^{\circ} \mathrm{C}$ ). The chloroform treatments were centrifuged (Eppendorf 5810R, Hamburg, Germany) at $4100 \times g$ for $5 \mathrm{~min}$. The aqueous upper phase was recovered and remaining traces of chloroform were removed by evaporation (overnight at $4{ }^{\circ} \mathrm{C}$ ). Positive controls, i.e. viruses not treated with solvent, underwent the same evaporation process. For all treatments, virus infectivity was tested by most probable number (MPN) endpoint dilution assay (Suttle, 1993).

\subsection{Experimental procedures of host lipid dynamics}

For the viral infection experiment, $2 \mathrm{~L}$ cultures of exponentially growing $P$. globosa $\left(8.6 \times 10^{4}\right.$ cells $\left.\mathrm{mL}^{-1}\right)$ were used. Duplicate cultures were inoculated with fresh $0.2 \mu \mathrm{m}$ filtered (Minisart high flow Syringe Filter; Sartorius A.G., Göttingen, Germany) PgV lysate, obtaining a virus to host ratio of $55: 1$. The duplicate non-infected control cultures were inoculated with the same volume of autoclaved seawater. Samples for algal abundance $(3.5 \mathrm{~mL}), \mathrm{PgV}$ abundance $(1 \mathrm{~mL})$, and IPL composition $(150 \mathrm{~mL})$ were taken at regular intervals until the cultures were completely lysed. Algal samples were fixed with a $1 \%$ final concentration of formaldehyde: hexamine solution $(18 \% v / v: 10 \% w / v)$. Samples for virus enumeration were fixed with $25 \%$ gluteraldehyde (EM grade; Sigma-Aldrich, St. Louis, USA) to a final concentration of $0.5 \%$, and incubated for $30 \mathrm{~min}$ at $4{ }^{\circ} \mathrm{C}$, after 
which the samples were flash-frozen in liquid nitrogen. IPL samples were filtered through $47 \mathrm{~mm}$ Whatman GF/F filters (nominal pore size $0.7 \mu \mathrm{m}$; Maidstone, UK), folded in aluminum foil and flash-frozen in liquid nitrogen. All samples were stored at $-80^{\circ} \mathrm{C}$ until analysis. A second experiment was conducted, with a similar set-up as described above, to allow isolation of $\mathrm{PgV}$ after complete host-cell lysis (48 h).

\subsection{Isolation of PgV for lipid extraction}

Viruses were isolated and purified according to Vardi et al. (2009) with the following adjustments to the original protocol. The $10 \mathrm{~L}$ of lysate was gently filtered through Whatman GF/C filters (47 mm diameter; nominal pore size $1.0 \mu \mathrm{m}$; Maidstone, UK) in 10 separate batches of $1 \mathrm{~L}$ to prevent clogging. After concentration by $30 \mathrm{kDa}$ tangential flow filtration (Vivaflow 200; Sartorius Stedim Biotech $\mathrm{GmbH}$, Göttingen, Germany), the remaining $50 \mathrm{~mL}$ of concentrated lysate was spun down into a $25 \%$ OptiPrep $^{\mathrm{TM}}$ (iodixanol) (Axis-Shield, Dundee, UK) solution. This was carried out by ultracentrifugation (Centrikon T-1080; Kontron Instruments, Watford, UK) in $12 \mathrm{~mL}$ ultraclear ultracentrifuge tubes (Beckman Coulter Inc., Brea, CA) in a swingout rotor (SW41TI; Beckman Coulter, Palo Alto, USA) at approximately $100000 \times g$ for $2 \mathrm{~h}$. Subsequently, the lower layer containing the $25 \%$ Optiprep $^{\mathrm{TM}}$ and viruses was pipetted on top of prepared density gradients containing 30, 35, 40 and $45 \%$ Optiprep $^{\mathrm{TM}}$. After ultracentrifugation (as described above, but at $200000 \times g$ for $4 \mathrm{~h}$ ), the tubes were pierced with a sterile syringe needle to take out the clearly visible band containing PgV. The sample was gently filtered onto $0.02 \mu \mathrm{m}$ Anodisc filters $(25 \mathrm{~mm}$ diameter; Whatman, Maidstone, UK), which where stored in $20 \mathrm{~mL}$ glass scintillation vials (Packard bioscience, Meriden, USA) at $-80^{\circ} \mathrm{C}$ until analysis. During each step viral abundance samples were taken to confirm the recovery of viruses during filtration and centrifugation.

\subsection{Algal and viral abundance}

Samples to use for algal and viral enumeration were analysed using a benchtop BD FACSCalibur flow cytometer with a $488 \mathrm{~nm}$ argon laser (BD Biosciences, San Jose, USA). Algal abundances were determined without dilution by chlorophyll red autofluorescence and side scatter (Marie et al., 1999). Virus samples were, once thawed, diluted 100 to 10000 -fold in sterile TE buffer $(\mathrm{pH}=8)$ according to Brussaard (2004). In short, $\mathrm{PgVs}$ were stained with the nucleic acid-specific dye SYBR Green I to a final concentration of $0.5 \times 10^{-4}$ of the commercial stock (Life technologies Ltd. Paisley, UK) for $10 \mathrm{~min}$ at $80^{\circ} \mathrm{C}$ and discriminated by their green fluorescence and side scatter signal. All flow cytometry data were analysed using CYTOWIN 4.31 (Vaulot, 1989).

\subsection{Intact polar lipid analysis}

After freeze-drying, the GF/F filters containing the infected $P$. globosa cells were cut into small pieces and extracted using a modified Bligh and Dyer (BD) extraction as described by Pitcher et al. (2011). All solvents used in the procedures described below were liquid chromatography/mass spectrometry (LC/MS) grade, with exception of the dichloromethane (DCM) which was high-performance liquid chromatography (HPLC) grade. A known volume of single-phase solvent mixture of methanol $(\mathrm{MeOH}): \mathrm{DCM}:$ phosphate buffer $(2: 1: 0.8, v: v: v)$ was added to the sample in a glass centrifuge tube and placed in an ultrasonic bath for $10 \mathrm{~min}$. The extract and residue were separated by centrifuging at $1000 \times g$ for $5 \mathrm{~min}$, and the solvent mixture collected in a separate glass flask; this was repeated three times. DCM and phosphate buffer were added to the single-phase extract to give a new ratio of $\mathrm{MeOH}: \mathrm{DCM}:$ phosphate buffer $(1: 1: 0.9, v: v: v)$, and to induce phase separation. The extract was centrifuged at $1000 \times g$ for $5 \mathrm{~min}$. The DCM phase was collected in a round-bottom flask and the $\mathrm{MeOH}$ : phosphate buffer phase was washed two additional times with DCM. The combined DCM phases were reduced under a stream of $\mathrm{N}_{2}$. The Anodisc filters containing the viral isolate were extracted in the same way, but were ground directly in the BD solvent mixture in a glass tube, using a spatula. The polypropylene ring surrounding the filter was removed after the first sonication step. A blank filter extraction showed no background IPL contaminants.

An aliquot of the BD extracts was dissolved in an injection solvent composed of hexane / isopropanol / water (72:27:1; $v / v / v)$ and filtered through a $0.45 \mu \mathrm{m}$ regenerated cellulose filter (4 mm diameter; Grace, Deerfield, USA) prior to analysis by HPLC electrospray ionization MS (HPLC-ESI-MS ${ }^{n}$ ) using methods modified from (Sturt et al., 2004). Briefly, HPLC separation was conducted on an Agilent 1200 series $L C$ equipped with a thermostated autoinjector, coupled to a Thermo LTQ XL linear ion trap with Ion Max source with electrospray ionization (ESI) probe (Thermo Scientific, Waltham, MA). For details of gradient, column and ESI setting see Sinninghe Damsté et al. (2011). The IPLs were identified using a positive ion mode $(\mathrm{m} / \mathrm{z} 400-2000)$. The four most abundant ions from each positive ion full scan were fragmented first to $\mathrm{MS}^{2}$ (normalized collision energy (NCE) 25, isolation width (IW) 5.0, activation Qz 0.175) and then to $\mathrm{MS}^{3}$ (NCE 25, IW 5.0, Qz 0.175). Structural identification of the IPLs was carried out by comparison with fragmentation patterns of authentic standards as described in Brandsma et al. (2012a). Due to the varying ionization efficiencies of the IPLs examined in this study we can not calculate the actual abundance of the different lipid groups. Instead, we compare the apparent abundance of the IPLs in the total ion chromatograms, which may not reflect the actual relative concentrations of the different IPLs in the cells. In addition to 
Table 1. The relative distribution of the intact polar lipids (IPLs) in the control and infected P. globosa cultures at three time points and in the virus PgV-07T. Relative ionization of the compounds per treatment is depicted by plusses (+), or by "Tr." (trace) when below $5 \%$ of the total ionization. Minus (-) shows a complete absence. Due to their low abundance, detection of the PEs and DMPEs was not consistent; hence they were not included in the IPL sum.

\begin{tabular}{clcccccccc}
\hline & & MGDGs & DGDGs & SQDGs & PC & PG & DGTA & DGCC & GSL \\
\hline T0 & Control & ++ & + & Tr. & +++ & Tr. & + & ++ & Tr. \\
& Infected & ++ & + & Tr. & +++ & Tr. & + & ++ & Tr. \\
T24 & Control & + & + & Tr. & +++ & + & + & ++ & Tr. \\
& Infected & + & + & Tr. & +++ & + & + & ++ & Tr. \\
T48 & Control & + & + & Tr. & +++ & + & + & ++ & Tr. \\
& Infected & + & + & Tr. & +++ & + & + & ++ & Tr. \\
& PgV & Tr. & Tr. & - & ++++ & + & + & ++ & Tr. \\
\hline
\end{tabular}

the characterization of routinely described glycolipids, phospholipids and betaine lipids, we surveyed extracts for the presence of viral glycosphingolipids (vGSL) using the mass spectral characteristics described by Vardi et al. (2009) and those of $\mathrm{C}_{18: 2} / \mathrm{C}_{16: 0}$ glucosylceramide standard (Avanti Polar Lipids, Inc., Alabaster, USA). In order to ascertain that our instrument sensitivity was sufficient to detect these compounds, a positive control was carried out by analysis of an extract of E. huxleyi CCMP1516 (CCMP Culture collection, Bigelow) infected by EhV-86 (Wilson, personal communication, 2013). For this host-virus system we were able to detect the described viral glycosphingolipid in $\mathrm{MS}^{1}$ as its protonated molecule $\left([\mathrm{M}+\mathrm{H}]^{+}\right)$at $m / z$ 804, which gave rise to a diagnostic loss of $162 \mathrm{Da}$ in $\mathrm{MS}^{2}$ (data not shown), as in Vardi et al. (2009).

\section{Results}

\subsection{Algal growth and viral dynamics}

The non-infected $P$. globosa cultures grew at maximum growth rate $\left(1.1 \mathrm{~d}^{-1}\right)$ throughout the experiment, while viral infection led to a rapid decline of cell numbers and full lysis $48 \mathrm{~h}$ post-infection (pi; Fig. 1a). The one-step viral growth curve showed a release of newly produced viruses within $12 \mathrm{~h}$ pi (Fig. 1b) resulting in a burst size of 288 viruses cell ${ }^{-1}$. PgVs stained well with the lipophilic dye FM 1-43 (Fig. 2a). The abundance of the FM 1-43 stained PgVs was slightly lower $(8 \%)$ than the SYBR green I stained $\mathrm{PgV}$ abundance (Fig. 2b). The presence of a viral lipid membrane was, furthermore, confirmed by total loss of infectivity of PgV-07T upon treatment with 10 and $50 \%(v / v)$ diethyl ether or chloroform.

\subsection{Intact polar lipids in P. globosa and PgV}

Ten classes of IPLs (see Fig. 3 for structures) were detected in the cultures at the start of the experiment (Fig. 4a), i.e. the glycolipids monogalactosyldiacylglycerols (MGDGs), digalactosyldiacylglycerols (DGDGs), gly- cosphingolipids (GSLs) and sulfoquinovosyldiacylglycerols (SQDGs); the phospholipids phosphatidylethanolamines (PEs), dimethylphosphatidylethanolamines (DMPEs), phosphatidylglycerols (PGs) and phosphatidylcholines (PCs) and the betaine lipids diacylglyceryl hydroxymethyltrimethyl$\beta$-alanines (DGTAs) and diacylglyceryl carboxyhydroxymethylcholines (DGCCs). After 24 and $48 \mathrm{~h}$ the noninfected controls only showed minor changes in IPL composition, with a decrease of the relative contribution of the MGDGs and an increase of the PGs relative to the initial contributions (Table 1, Fig. 4b). Comparison between the control and virally infected cultures did not reveal any substantial differences (Fig. 4c, Table 1). The algal host DMPEs, which were detected in low levels in the control cultures at T48, were not detected in the infected cultures at T48, most likely due to the decrease in cellular material over the course of the viral infection. Glycosphingolipids with $[\mathrm{M}+\mathrm{H}]^{+}$ions of $m / z$ 780, 778, 766 and 764 were detected. These were all identified by the presence of a $\mathrm{MS}^{2}$ product ion arising from a loss of $180 \mathrm{Da}$ from the $[\mathrm{M}+\mathrm{H}]^{+}$ion, and a less abundant product ion arising from loss of $162 \mathrm{Da}$. The $\mathrm{MS}^{3}$ spectra of $m / z 778$ and 780 both contained product ions at $m / z 257$ and 275 , the same as those ascribed to the $C_{19: 3}$ alkyl chain of host-glycosphingolipids (hGSL) in E. huxleyi (Vardi et al., 2012). While the $\mathrm{MS}^{2}$ and $\mathrm{MS}^{3}$ spectra of both $m / z 766$ and 764 exhibited similar characteristics to those arising from the $m / z 780$ and 778 ions, full structural elucidation was not possible from ion-trap MS spectra. As all four glycosphingolipids were found equally present in both the infected and control cultures and were thus not affected by viral infection; further structural identification of the compounds fell outside of the scope of this study. Viral glycosphingolipids (vGSLs), with a dominant loss of $162 \mathrm{Da}$, as described by Vardi (2009), were not detected.

The fatty acid moieties of the IPLs (IPL-FAs), determined using the fragment patterns observed in the $\mathrm{MS}^{2}$ spectra of the $[\mathrm{M}+\mathrm{H}]^{+}$ions exhibited only minor changes in composition due to the viral infection (data not shown). For example, the MGDG-FA distribution did not change significantly in the control cultures over the $48 \mathrm{~h}$ experiment. However, in 

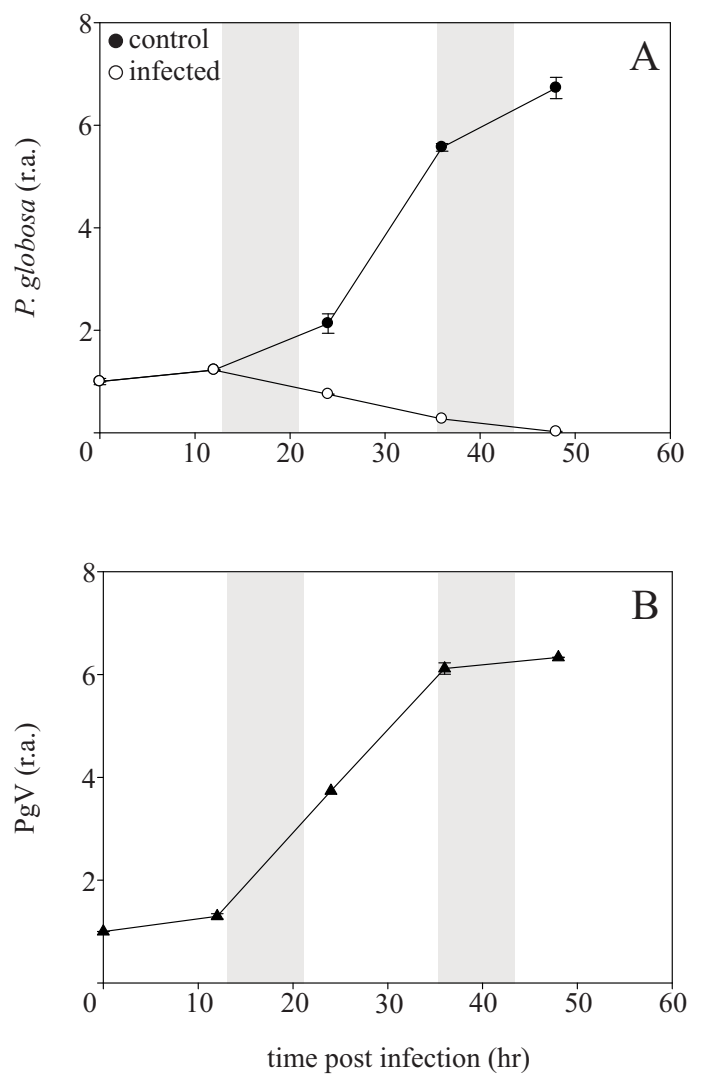

Fig. 1. Abundances (normalized to T0) of algal host Phaeocystis globosa (A), and of the virus PgV-07T (B). Closed symbols represent the non-infected cultures, the open symbols the virally infected cultures. If standard deviation bar is not visible, it falls within the symbol. Shaded areas depict dark (night) period and r.a. stands for relative abundance.

the infected cultures there was a relative increase in $\mathrm{C}_{14: 0,18: 1}$ and $\mathrm{C}_{16: 0,18: 1}$ MGDGs, with a concomitant decrease or little change in the polyunsaturated MGDG-FAs and no change in the saturated MGDG-FAs (data not shown). Similarly, there were differences in the relative contribution of different PCFAs (data not shown) between the infected and control cultures at T48. The infected cultures contained slightly more of the $\mathrm{C}_{32: 4}, \mathrm{C}_{34: 4}, \mathrm{C}_{34: 5}$ and $\mathrm{C}_{40: 11}$ PC-FAs, although somewhat less of the $\mathrm{C}_{40: 10}, \mathrm{C}_{42: 11}$ and $\mathrm{C}_{44: 12}$ PC-FAs.

The IPL composition of $\mathrm{PgV}-07 \mathrm{~T}$ was quite distinct from that of the host, with the PCs forming a much more substantial part of the IPLs than in the host. Of the other phospholipids (Fig. 4d, Table 1), PGs were also present, but PEs and DMPEs were not detected. Both betaine classes were detected in the viral isolate. The glycolipids were responsible for the largest difference in IPL composition between the virus and host. The contribution of the MGDGs and DGDGs to the sum of IPLs was reduced in the virus relative to the host and the SQDGs were not detected at all. As mentioned
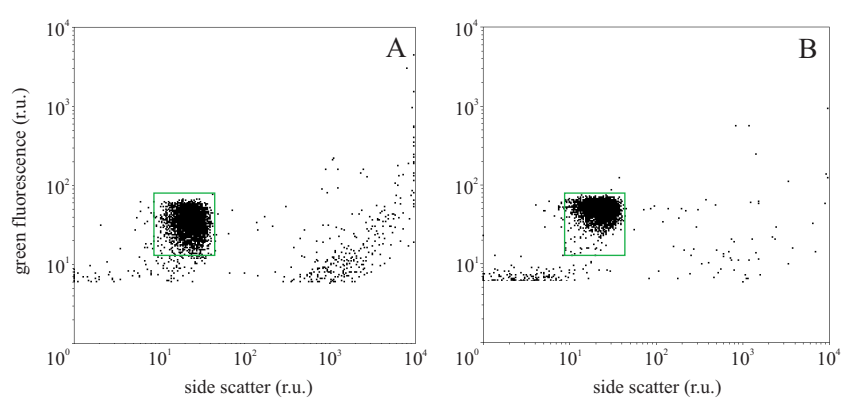

Fig. 2. Flow cytometric signatures of $\mathrm{PgV}$ after staining with the green fluorescent lipid stain FM 1-43 (A) and the nucleic acidspecific dye SYBR Green I (B); r.u. stands for relative units.

above for the host, the vGSLs described by Vardi (2009), were also not detected in the virus.

The IPL-FA composition of PgV-07T was for some IPL classes quite distinct from that of $P$. globosa (Tables S1 and 2). The MGDGs, DGDGs and DMPEs in the virus comprised a smaller range of fatty acids than those in the host while the PGs, DGCCs and DGTAs in the virus exhibited almost identical ranges of fatty acids as they had in the host. Only the virus PCs contained additional fatty acids that were not detected in the host: $\mathrm{C}_{34: 7}, \mathrm{C}_{36: 8-10}, \mathrm{C}_{38: 4}, \mathrm{C}_{38: 10}, \mathrm{C}_{42: 12}, \mathrm{C}_{42: 13}$ and $\mathrm{C}_{44: 11}$ PC-FAs (Table S1 and 2).

\section{Discussion}

The present study showed that the IPL composition of the prymnesiophyte $P$. globosa G(A) was not substantially affected by viral infection, except for minor changes in the IPL-FA combinations. However, the IPL composition of the virus PgV-07T was different from the host's lipid composition, suggesting a selective acquisition of these compounds. We have not encountered any virus-specific lipids that were not detected in the non-infected host. This is in contrast to the finding of viral glycosphingolipids in another prymnesiophyte virus-host model system, i.e. EhV-86 and Emiliania huxleyi CCMP374. Phylogenetically related virus-phytoplankton systems may thus have very different lipid-related features during viral propagation.

\subsection{Impact of viral infection on host lipid composition}

The IPL classes detected in P. globosa originate from all cellular components, including the cell membrane as well as intracellular membranes from the chloroplasts and other organelles. In previous studies, environmental factors such as irradiance (Guschina and Harwood, 2009), but also viral infection (Vardi et al., 2009) were shown to affect the composition of these host IPLs. For instance, it is known that viral infection typically induces a membranous rearrangement in the host to compartmentalize viral replication (den Boon et al., 2010). In our study we did not observe a strong impact 
<smiles>[R]C(=O)OC(COC([R])C)COC1OC(CO)C(O)C(O)C1O</smiles>

MGDG<smiles>[R]C(=O)OCC(COC1OC(CO)C(O)C(O)C1O)OC([R])=O</smiles>

SQDG<smiles>[R]C(=O)OCC(COC(=O)O)OC(=O)C([R])C(=O)OCC[N+](C)(C)C</smiles>

PC<smiles>[R]C(=O)OCC(COP(=O)(O)OCCN)OC([Y])=O</smiles>

PE<smiles>[R]C(=O)OCC(COCC(C[N+](C)(C)C)C(=O)O)OC([R])=O</smiles>

DGTA<smiles>[R]C(=O)OCC(COC1OC(COC2OC(CO)C(O)C(O)C2O)C(O)C(O)C1O)OC([R])C</smiles>

DGDG<smiles>[Y]C(=O)N[C@@H](CO[C@H]1O[C@H](CO)[C@@H](O)[C@H](O)[C@H]1O)C([Y])O</smiles>

GSL<smiles>[R]C(=O)OCC(COP(=O)(O)OCC(O)CO)OC([R])=O</smiles>

PG<smiles>[R]C(=O)OCC(COP(=O)(O)OCCN(C)C)OC([R])=O</smiles>

DMPE<smiles>[R]C(=O)OCC(COC(OCCC[N+](C)(C)C)C(=O)O)OC([R])=O</smiles>

DGCC

Fig. 3. Structural formulas of the main IPL classes belonging to the glycolipids monogalactosyldiacylglycerols (MGDGs), digalactosyldiacylglycerols (DGDGs), glycosphingolipids (GSLs) and sulfoquinovosyldiacylglycerols (SQDGs); the phospholipids phosphatidylethanolamines (PEs), dimethylphosphatidylethanolamines (DMPEs), phosphatidylglycerols (PGs) and phosphatidylcholines (PCs) and the betaine lipids diacylglyceryl hydroxymethyltrimethyl- $\beta$-alanines (DGTAs) and diacylglyceryl carboxyhydroxymethylcholines (DGCCs). The acyl groups are represented by $\mathrm{R} 1$ and $\mathrm{R} 2$.

by viral infection on the composition of IPL classes of $P$. globosa, nor did the diel cycle have an effect. Minor differences in the IPL-FA distribution of some of the IPLs associated with viral infection were observed. Evans et al. (2009) showed that viral infection of E. huxleyi CCMP1516 led to a relative decrease in polyunsaturated fatty acids. In our study, the changes in host IPL-FAs during infection were only minor, i.e. a decrease of certain FAs amongst the MGDGs, DGDGs and DMPEs.
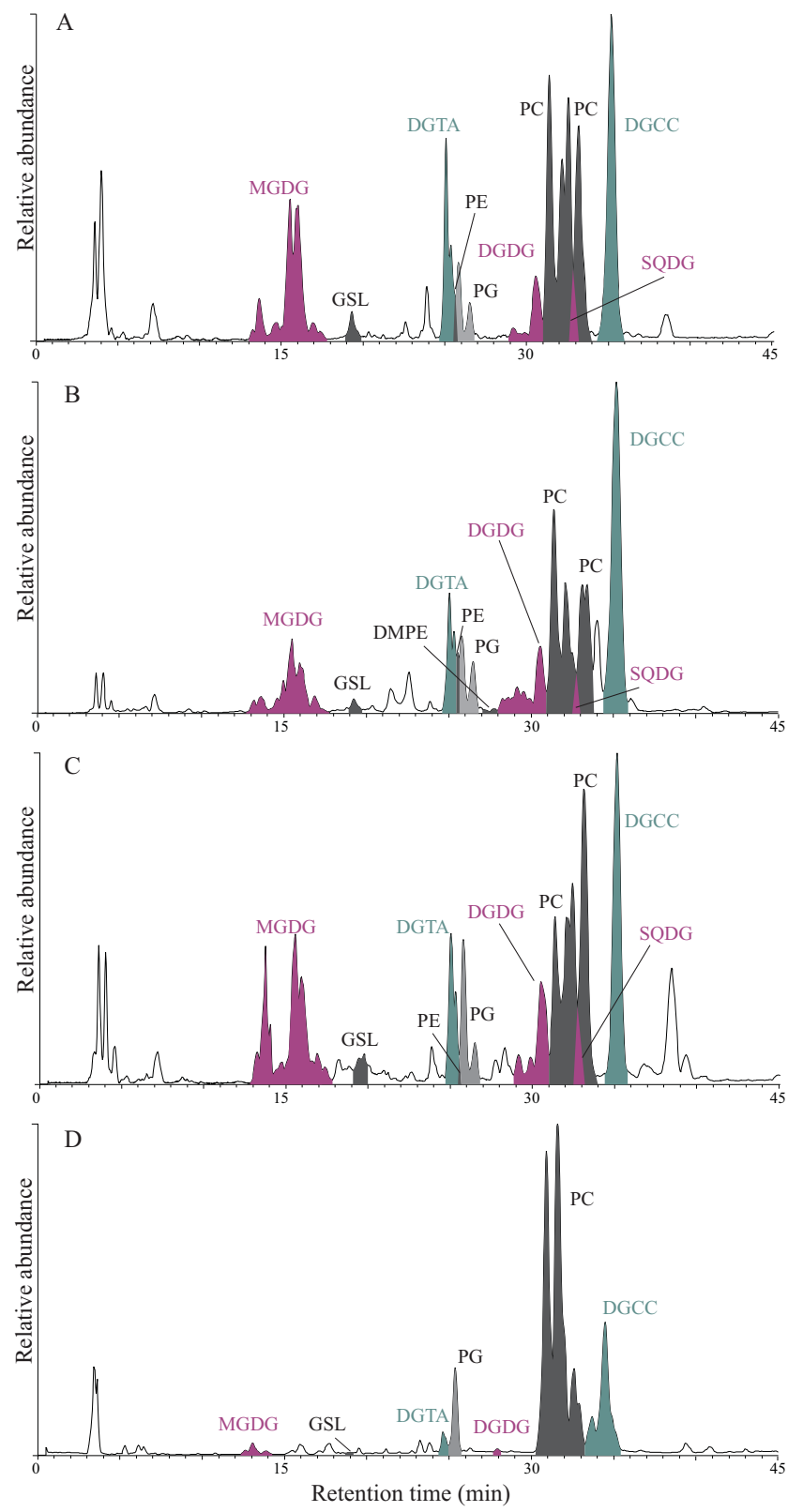

Fig. 4. Partial base-peak chromatograms (MS1, $m / z$ 400-2000) of non-infected $P$. globosa at T0 (A) and T48 (B), virally infected $P$. globosa at T48 (C), and the virus PgV-07T (D).

\subsection{Acquisition of intact polar lipids from the host}

By staining the viruses with a lipophilic dye, we have shown that $\mathrm{PgV}-07 \mathrm{~T}$ possesses a lipid membrane. The complete loss of infectivity of $\mathrm{PgV}-07 \mathrm{~T}$ after treatment with diethyl ether and chloroform indicates that this membrane plays a crucial role in the infection of P. globosa. Based on transmission electron microscopy (TEM) thin-section images, the Group I PgVs (i.e. $150 \mathrm{~nm}$ large NCLDVs with a thin outer layer surrounding a layered inner core, to which PgV-07T 
belongs), are assembled in the cytoplasm and leave the host after disruption of the cell membranes (Baudoux and Brussaard, 2005). Thus, in contrast with EhV-86 (Mackinder et al., 2009), $\mathrm{PgV}$ seems to obtain its lipid membrane in the host cytoplasm and not from the cell membrane. The lipids of $\mathrm{PgV}$ are then either allocated, newly synthesized or obtained from other membranes, such as the endoplasmatic reticulum (E.R.) or the Golgi system (den Boon et al., 2010; Heaton and Randall, 2011). Meints et al. (1986) showed the appearance of membranous structures at the sites of virus assembly in Chlorella sp. This virus, called PBCV-1, belongs to the Phycodnaviridae and is thought to obtain these lipid membranes from the host endoplasmatic reticulum (Wilson et al., 2009). The origin and patterns of $\mathrm{PgV}$ replication in the host cell, i.e. formation of virions in the cytoplasm and virus release in a single burst (Baudoux and Brussaard, 2005), show a strong resemblance to PBCV-1 (Meints et al., 1986). Using electron cryomicroscopy, Yan et al. $(2000,2005)$ confirmed that not only PBCV-1, but also the Phaeocystis pouchetii virus PpV01, contains a membrane covering the inside of the capsid. Regarding the similarity in patterns of infection between these viruses and PgV-07T, it is likely that PgV-07T also possesses an intracapsid membrane.

Of the viral IPL classes, the phospholipids appear to be acquired in higher proportions than the glyco- and betaine lipids. The PCs, considered to be the most dominant phospholipids in phytoplankton (Van Mooy et al., 2009) were well represented in $P$. globosa and, probably due to its ubiquity in all cellular membranes (Thompson, 1996), in the virus as well. Some viral PCs contained additional fatty acids that were not found in the host. While it is possible that these PCs were the products of de novo synthesis, it can also be that they were present in the host but were in too low a concentration to be detected. Indeed, in PgV they constitute only a minor fraction of the total amount of PCs (data not shown). The PgV extract contained a higher proportion of PCs than the host and may have also contained less sample matrix, factors which would make it easier to detect individual PCs that are present in low abundance.

The second most important group of phospholipids in $P$. globosa, the PGs, are known to be abundant in chloroplasts and other organelles, such as the endoplasmatic reticulum (Schwertner and Biale, 1973). The source of the viral lipid membrane could be associated with such organelles. The PEs and DMPEs were not detected in the virus, but even in the infected cultures they were only present in trace amounts. These compounds have been shown to be precursors in the methylation pathway of PC in bacteria (Aktas and Narberhaus, 2009) and yeast (Kanipes and Henry, 1997), while this is the case for PEs in the phytoplankton species Chlamydomonas reinhardtii (Yang et al., 2004). PEs and DMPEs have furthermore been shown to be associated to small organelles such as mitochondria (Schwertner and Biale, 1973). For the infected lysing P. globosa cultures, such organelles might have been lost by passing through the GF/F filter during sampling of the infected cultures.

The betaine lipids in the $\mathrm{PgV}$ membrane were relatively low in relation to their contribution to the total lipids in the algal host. Interestingly, DGTAs have been found in algal thylakoid membranes (Murata, 1998). TEM thin sections and epifluorescence microscopy of infected $P$. globosa cells (data not shown) illustrate that the integrity of the chloroplast of $P$. globosa is largely unaffected far into the viral growth cycle, leaving the chloroplast membranes intact. The DGTAs in $P$. globosa might also be mainly associated with the membranes of the unaffected chloroplast and therefore present in lower relative amounts in the membrane of PgV-07T.

The relative loss of glycolipids, including the apparently complete loss of SQDGs in the virus, is probably due to the same process. The four classes of glycolipids detected in $P$. globosa are generally associated with the chloroplast in algae and higher plants (Guschina and Harwood, 2009; Sato, 2009 ). With a roughly $50 \%$ contribution, the MGDGs often comprise the majority of the chloroplast lipids, while the other half is composed of DGDGs, SQDGs and phospholipids. GSLs have not been found in chloroplasts, but their synthesis is directly related to chloroplast metabolism and vice versa; the disruption of sphingolipid biosynthesis was found to lead to the disruption of the chloroplast membranes in the vascular plant Datura stramonium (Abbas et al., 1992; Chen et al., 2009). Additionally, GSLs are also found in plant cell membranes, where they can account for up to $27 \mathrm{~mol} \%$ of lipids (Chen et al., 2009). In this case both the association to the chloroplast and the cell membranes could account for the relative loss of GSLs in PgV-07T.

In summary, our results suggest that PgV-07T acquired its lipid membrane mainly in the host cytoplasm and that the chloroplast membranes as well as the cell membrane were not utilized. Since we did not find any group of IPLs in the infected cultures or the virus that were not also detected in the non-infected culture, we hypothesize that PgV-07T selectively recruits its lipids from existing membranes, such as the E.R. or the Golgi apparatus. Examination of the composition of these membranes could clarify this issue.

\subsection{Glycosphingolipids as markers for viral infection}

Although we detected a group of GSLs in both the noninfected and infected P. globosa cells, we did not observe the specific vGSLs that Vardi et al. (2009) described as being synthesized in infected $E$. huxleyi cells and being part of the viral membrane. Indeed, the four viral genes involved in the synthesis of this vGSL and transcribed during infection (Wilson et al., 2005) were found to be absent in the genome of PgV-016T (Santini et al., 2013). This virus belongs to the same group of PgVs (Group I), as PgV-07T as PgV-07T, as based on e.g. genome and particle size (Baudoux and Brussaard, 2005), but could still be different in other characteristics since it was found to belong to a different phylogenetic 
cluster based on the DNA polymerase gene (Santini et al., 2013). The difference in infection mechanisms is especially interesting since P. globosa and E. huxleyi both belong to the same class of algae, namely the Prymnesiophyceae, and both $\mathrm{PgV}-07 \mathrm{~T}$ and EhV-86 are NCLDVs (Baudoux and Brussaard, 2005; Wilson et al., 2005). E. huxleyi has been extensively used as a model system to study specific features of algal virus-host interactions, such as caspase activity (Bidle et al., 2007), host entry, departure and viral envelope acquisition (Mackinder et al., 2009) and now the involvement of vGSLs (Vardi et al., 2009). Comparison of these and additional virological aspects with those of PgV-07T (Group I) and other known members of phytoplankton infecting NCLDVs, i.e. PgVs from Group II, PpV-01, PBCV-1, Chrysochromulina ericina virus (CeV-01B) and Pyramimonas orientalis virus (PoV-01B), suggests that the infection strategy of EhV-86 is rather uncommon amongst the known phytoplankton viruses (Yan et al., 2000; Sandaa et al., 2001; Baudoux and Brussaard, 2005; Mackinder et al., 2009; Van Etten et al., 2010). Thus, the use of lipid biomarkers for viral infection of phytoplankton (Vardi et al., 2012) might only be successful for specific virus-host systems such as E. huxleyi and EhV-86 and not be generally applicable. More data on lipids in other virus-phytoplankton systems must be acquired in order to address this issue.

\section{Supplementary material related to this article is available online at http://www.biogeosciences.net/11/185/ 2014/bg-11-185-2014-supplement.pdf.}

Acknowledgements. We thank two anonymous reviewers for their constructive comments which improved the manuscript. We dedicate this paper to Carlo Heip ( $† 15$ February 2013). D. S. Maat was supported by a grant to C. P. D. Brussaard of the Royal Netherlands Institute for Sea Research (NIOZ) for funding of this project. NIOZ is an institute of the Netherlands Organization for Scientific Research (NWO). N. J. Bale was supported by a grant (839.08.331) to J. S. Sinninghe Damsté of The National Ocean and Coastal Research Programme (ZKO) supported by NWO.

Edited by: G. Herndl

\section{References}

Abbas, H. K., Paul, R. N., Boyette, C. D., Duke, S. O., and Vesonder, R. F.: Physiological and ultrastructural effects of fumonisin on Jimsonweed leaves, Can. J. Botany, 70, 1824-1833, 1992.

Aktas, M. and Narberhaus, F.: In vitro characterization of the enzyme properties of the phospholipid N-methyltransferase PmtA from agrobacterium tumefaciens, J. Bacteriol., 191, 2033-2041, 2009.
Arrigo, K. R., Robinson, D. H., Worthen, D. L., Dunbar, R. B., DiTullio, G. R., VanWoert, M., and Lizotte, M. P.: Phytoplankton community structure and the drawdown of nutrients and $\mathrm{CO}_{2}$ in the Southern Ocean, Science, 283, 365-367, 1999.

Bamford, D. H., Caldentey, J., and Bamford, J. K. H.: Bacteriophage PRD1 - A broad-host-range dsDNA Tectivirus with an internal membrane, Advances in Virus Research, 45, 281-319, 1995.

Baudoux, A. C. and Brussaard, C. P. D.: Characterization of different viruses infecting the marine harmful algal bloom species Phaeocystis globosa, Virology, 341, 80-90, 2005.

Baudoux, A.-C. and Brussaard, C. P. D.: Influence of irradiance on virus-algal host interactions, J. Phycol., 44, 902-908, 2008.

Bidle, K. D., Haramaty, L., Barcelos e Ramos, J., and Falkowski, P.: Viral activation and recruitment of metacaspases in the unicellular coccolithophore, Emiliania huxleyi, P. Natl. Acad. Sci. USA, 104, 6049-6054, 2007.

Brandsma, J., Hopmans, E. C., Brussaard, C. P. D., Witte, H. J., Schouten, S., and Sinninghe Damsté, J. S.: Spatial distribution of intact polar lipids in North Sea surface waters: Relationship with environmental conditions and microbial community composition, Limnol. Oceanogr., 57, 959-973, 2012a.

Brandsma, J., Hopmans, E. C., Philippart, C. J. M., Veldhuis, M. J. W., Schouten, S., and Sinninghe Damsté, J. S.: Low temporal variation in the intact polar lipid composition of North Sea coastal marine water reveals limited chemotaxonomic value, Biogeosciences, 9, 1073-1084, doi:10.5194/bg-9-10732012, 2012b.

Brussaard, C. P. D.: Optimization of procedures for counting viruses by flow cytometry, Appl. Environ. Microb., 70, 1506-1513, 2004.

Brussaard, C. P. D. and Martínez Martínez, J.: Algal bloom viruses, in: Plant Viruses, edited by: Teixeira da Silva, J. A., Global Science Books, 1-13, 2008.

Brussaard, C. P. D., Short, S. M., Frederickson, C. M., and Suttle, C. A.: Isolation and phylogenetic analysis of novel viruses infecting the phytoplankton Phaeocystis globosa (Prymnesiophyceae), Appl. Environ. Microb., 70, 3700-3705, 2004.

Chen, M., Cahoon, E. B., Saucedo-Garcia, M., Plasencia, J., and Gavilanus-Ruiz, M.: Plant sphingolipids: structure, synthesis and function, in: Lipids in photosynthesis: essential and regulatory functions, edited by: Hajime Wada, N. M., Springer, Dordrecht, 77-115, 2009.

Cottrell, M. T. and Suttle, C. A.: Wide-spread occurrence and clonal variation in viruses which cause lysis of a cosmopolitan, eukaryotic marine phytoplankter, Micromonas-pusilla, Mar. Ecol.-Prog. Ser., 78, 1-9, 1991.

den Boon, J. A., Diaz, A., and Ahlquist, P.: Cytoplasmic Viral Replication Complexes, Cell Host Microbe, 8, 77-85, 2010.

Evans, C., Pond, D. W., and Wilson, W. H.: Changes in Emiliania huxleyi fatty acid profiles during infection with E-huxleyi virus 86: physiological and ecological implications, Aquat. Microb. Ecol., 55, 219-228, 2009.

Feldman, H. A. and Wang, S. S.: Sensitivity of various viruses to chloroform, Exp. Biol. Med., 106, 736-738, 1961.

Guillard, R. R. L.: Culture of phytoplankton for feeding marine invertebrates, in: Culture of Marine Invertebrate Animals., edited by: Smith, W. L., and Chanley, M. H., Plenum Press, New York, USA., 229-239, 1975. 
Guschina, I. A. and Harwood, J. L.: Algal lipids and effect of the environment on their biochemistry, in: Lipids in aquatic ecosystems, edited by: Arts, M. T., Kainz, M. J., and Brett, M. T., Springer, Dordrecht, the Netherlands, 1-24, 2009.

Harrison, P. J., Waters, R. E., and Taylor, F. J. R.: A broad-spectrum artificial seawater medium for coastal and open ocean phytoplankton, J. Phycol., 16, 28-35, 1980.

Heaton, N. S. and Randall, G.: Multifaceted roles for lipids in viral infection, Trends Microbiol., 19, 368-375, 2011.

Kanipes, M. I. and Henry, S. A.: The phospholipid methyltransferases in yeast, Biochim. Biophys. Acta, 1348, 134-141, 1997.

Mackinder, L. C. M., Worthy, C. A., Biggi, G., Hall, M., Ryan, K. P., Varsani, A., Harper, G. M., Wilson, W. H., Brownlee, C., and Schroeder, D. C.: A unicellular algal virus, Emiliania huxleyi virus 86, exploits an animal-like infection strategy, J. Gen. Virol., 90, 2306-2316, 2009.

Marie, D., Brussaard, C. P. D., Thyrhaug, R., Bratbak, G., and Vaulot, D.: Enumeration of marine viruses in culture and natural samples by flow cytometry, Appl. Environ. Microb., 65, 45-52, 1999.

Meints, R. H., Lee, K., and Vanetten, J.L.: Assembly site of the virus PBCV-1 in a Chlorella-like green-alga - ultrastructural studies, Virology, 154, 240-245, 1986.

Moon-van der Staay, S. Y., van der Staay, G. W. M., Guillou, L., Vaulot, D., Claustre, H., and Medlin, L. K.: Abundance and diversity of Prymnesiophytes in the picoplankton community from the equatorial Pacific Ocean inferred from 18S rDNA sequences, Limnol. Oceanogr., 45, 98-109, 2000.

Murata, N. and Siegenthaler, P.: Lipids in photosynthesis: an overview, in: Lipids in photosynthesis: structure, function and genetics, edited by: Siegenthaler, P., Murata, N., Kluwer Academic Publishers, Dordrecht, the Netherlands, 1-20, 1998.

Olsen, R. H., Siak, J. S., and Gray, R. H.: Characteristics of PRD1, a plasmid-dependent broad host range DNA bacteriophage, J. Virol., 14, 689-699, 1974.

Pitcher, A., Villanueva, L., Hopmans, E. C., Schouten, S., Reichart, G.-J., and Sinninghe Damsté, J. S.: Niche segregation of ammonia-oxidizing archaea and anammox bacteria in the Arabian Sea oxygen minimum zone, ISME J., 5, 1896-1904, 2011.

Sandaa, R. A., Heldal, M., Castberg, T., Thyrhaug, R., and Bratbak, G.: Isolation and characterization of two viruses with large genome size infecting Chrysochromulina ericina (Prymnesiophyceae) and Pyramimonas orientalis (Prasinophyceae), Virology, 290, 272-280, 2001.

Santini, S., Jeudy, S., Bartoli, J., Poirot, O., Lescot, M., Abergel, C., Barbe, V., Wommack, K. E., Noordeloos, A. M., Brussaard, C. P. D., and Claverie, J. M.: The genome of Phaeocystis globosa virus $\mathrm{PgV}-16 \mathrm{~T}$ highlights the common ancestry of the largest known DNA viruses infecting eukaryotes, P. Natl. Acad. Sci. USA, 10800-10805, 2013.

Sato, N. and Wada, H.: Lipid biosynthesis and it regulation in cyanobacteria, in: Lipids in photosynthesis: essential and regulatory functions, edited by: Hajime Wada, N. M., Springer, Dordrecht, The Netherlands, 157-177, 2009.

Schoemann, V., Becquevort, S., Stefels, J., Rousseau, W., and Lancelot, C.: Phaeocystis blooms in the global ocean and their controlling mechanisms: a review, J. Sea Res., 53, 43-66, 2005.

Schwertner, H. A. and Biale, J. B.: Lipid composition of plant mitochondria and of chloroplasts, J. Lipid. Res., 14, 235-242, 1973.
Sheik, A. R., Brussaard, C. P. D., Lavik, G., Foster, R. A., Musat, N., Adam, B., and Kuypers, M. M. M.: Viral infection of Phaeocystis globosa impedes release of chitinous star-like structures: quantification using single cell approaches, Environ. Microbiol., 15, 1441-1451, 2013.

Sinninghe Damsté, J. S., Rijpstra, W. I. C., Hopmans, E. C., Weijers, J. W. H., Foesel, B. U., Overmann, J., and Dedysh, S. N.: 13,16-Dimethyl octacosanedioic acid (iso-diabolic acid), a common membrane-spanning lipid of Acidobacteria subdivisions 1 and 3, Appl. Environ. Microb., 77, 4147-4154, 2011.

Smith, W. O., Codispoti, L. A., Nelson, D. M., Manley, T., Buskey, E. J., Niebauer, H. J., and Cota, G. F.: Importance of Phaeocystis blooms in the high-latitude ocean carbon cycle, Nature, 352, 514-516, 1991.

Stefels, J. and van Boekel, W. H. M.: Production of DMS from dissolved DMSP in axenic cultures of the marine-phytoplankton species Phaeocystis sp., Mar. Ecol.-Prog. Ser., 97, 11-18, 1993.

Sturt, H. F., Summons, R. E., Smith, K., Elvert, M., and Hinrichs, K. U.: Intact polar membrane lipids in prokaryotes and sediments deciphered by high-performance liquid chromatography/electrospray ionization multistage mass spectrometry - new biomarkers for biogeochemistry and microbial ecology, Rapid Commun. Mass. Sp., 18, 617-628, 2004.

Suttle, C. A.: Enumeration and isolation of viruses, in: Current Methods in Aquatic Microbial Ecology, edited by: Kemp, P. F., Sherr, B. F., Sherr, E. F., and Cole, J. J. , Lewis Publishers Boca Raton, Florida, 121-134, 1993.

Thompson, G. A.: Lipids and membrane function in green algae, Biochim. Biophys. Acta, 1302, 17-45, 1996.

Van Etten, J. L., Lane, L. C., and Dunigan, D. D.: DNA Viruses: The Really Big Ones (Giruses), in: Annu. Rev. Microbiol., edited by: Gottesman, S., and Harwood, C. S., Palo Alto, 82-99, 2010.

Van Mooy, B. A. S., Fredricks, H. F., Pedler, B. E., Dyhrman, S. T., Karl, D. M., Koblizek, M., Lomas, M. W., Mincer, T. J., Moore, L. R., Moutin, T., Rappe, M. S., and Webb, E. A.: Phytoplankton in the ocean use non-phosphorus lipids in response to phosphorus scarcity, Nature, 458, 69-72, 2009.

Vardi, A., Van Mooy, B. A. S., Fredricks, H. F., Popendorf, K. J., Ossolinski, J. E., Haramaty, L., and Bidle, K. D.: Viral glycosphingolipids induce lytic infection and cell death in marine phytoplankton, Science, 326, 861-865, 2009.

Vardi, A., Haramaty, L., Van Mooy, B. A. S., Fredricks, H. F., Kimmance, S. A., Larsen, A., and Bidle, K. D.: Host-virus dynamics and subcellular controls of cell fate in a natural coccolithophore population, P. Natl. Acad. Sci. USA, 109, 19327-19332, 2012.

Vaulot, D.: CYTOPC: Processing software for flow cytometric data. Signal and Noise 2:8, available at: http://www.sb-roscoff.fr/Phyto/index.php?option=com content\&task=view\&id=72\&Itemid=123, (last access: 7 Jun 2013), 1989.

Wilhelm, S. W. and Suttle, C. A.: Viruses and Nutrient Cycles in the Sea - Viruses play critical roles in the structure and function of aquatic food webs, Bioscience, 49, 781-788, 1999.

Wilson, W. H., Schroeder, D. C., Allen, M. J., Holden, M. T. G., Parkhill, J., Barrell, B. G., Churcher, C., Harnlin, N., Mungall, K., Norbertczak, H., Quail, M. A., Price, C., Rabbinowitsch, E., Walker, D., Craigon, M., Roy, D., and Ghazal, P.: Complete genome sequence and lytic phase transcription profile of a Coccolithovirus, Science, 309, 1090-1092, 2005. 
Wilson, W. H., Van Etten, J. L., and Allen, M. J.: The Phycodnaviridae: The story of how tiny giants rule the world, in: Current Topics in Microbiology and Immunology, edited by: van Etten, J. L., Springer-Verlag, Berlin Heidelberg, 1-24, 2009.

Yan, X. D., Olson, N. H., Van Etten, J. L., Bergoin, M., Rossmann, M. G., and Baker, T. S.: Structure and assembly of large lipidcontaining dsDNA viruses, Nat. Struct. Biol., 7, 101-103, 2000.
Yan, X. D., Chipman, P. R., Castberg, T., Bratbak, G., and Baker, T. S.: The marine algal virus PpV01 has an icosahedral capsid with $\mathrm{T}=219$ quasisymmetry, J. Virol., 79, 9236-9243, 2005.

Yang, W. Y., Moroney, J. V., and Moore, T. S.: Membrane lipid biosynthesis in Chlamydomonas reinhardtii: ethanolaminephosphotransferase is capable of synthesizing both phosphatidylcholine and phosphatidylethanolamine, Arch. Biochem. Biophys., 430, 198-209, 2004. 